\title{
Extreme Reduction of Disease in Oats Transformed with the 5' Half of the Barley Yellow Dwarf Virus-PAV Genome
}

\author{
Gennadiy Koev, B. R. Mohan, S. P. Dinesh-Kumar, Kimberly A. Torbert, David A. Somers, and W. Allen Miller
}

First, second, third, and sixth authors: Plant Pathology Department, Iowa State University, 351 Bessey Hall, Ames 50011-1020; and fourth and fifth authors: Department of Agronomy and Plant Genetics, University of Minnesota, 411 Borlaug Hall, St. Paul, MN 55108.

Current address of S. P. Dinesh-Kumar: Plant Gene Expression Center, 800 Buchanan Street, Albany, CA 94710.

Accepted for publication 23 June 1998.

\begin{abstract}
Koev, G., Mohan, B. R., Dinesh-Kumar, S. P., Torbert, K. A., Somers, D. A., and Miller, W. A. 1998. Extreme reduction of disease in oats transformed with the $5^{\prime}$ half of the barley yellow dwarf virus-PAV genome. Phytopathology 88:1013-1019.

Barley yellow dwarf viruses (BYDVs) are the most serious and widespread viruses of oats, barley, and wheat worldwide. Natural resistance is inadequate. Toward overcoming this limitation, we engineered virus-derived transgenic resistance in oat. Oat plants were transformed with the $5^{\prime}$ half of the BYDV strain PAV genome, which includes the RNA-dependent RNA polymerase gene. In experiments on T2- and T3-generation plants descended from the same transformation event, all BYDV-inoculated
\end{abstract}

ABSTRACT plants containing the transgene showed disease symptoms initially, but recovered, flowered, and produced seed. In contrast, all but one of the BYDV-PAV-inoculated nontransgenic segregants died before reaching $25 \mathrm{~cm}$ in height. Although all of the recovered transgenic plants looked similar, the amount of virus and viral RNA ranged from substantial to undetectable levels. Thus, the transgene may act either by restricting virus accumulation or by a novel transgenic tolerance phenomenon. This work demonstrates a strategy for genetically stable transgenic resistance to BYDVs that should apply to all hosts of the virus.

Additional keywords: biolistic transformation, luteovirus, RNA-mediated resistance, transgenic virus resistance.
Barley yellow dwarf luteoviruses (BYDVs) are the most ubiquitous and economically important viruses of small grains including wheat, barley, and oats $(14,22)$. Every year, BYDVs cause substantial yield losses in cereals wherever these crops are grown (30). Average yield losses of $15 \%$ in barley, $17 \%$ in wheat, and $25 \%$ in oats are common (22). In $1989,5 \%$ yield losses due to BYDVs would have been valued at $\$ 387.1$ million in wheat, $\$ 48.5$ million in barley, and \$28.0 million in oats in the United States alone (14).

Luteoviruses are phloem-limited and transmitted exclusively by specific aphid species. Based on genome organizations and other properties, BYDVs and other luteoviruses have been divided into two subgroups, I and II $(24,29)$. The 3 ' halves of the genomes of both luteovirus subgroups share a high degree of homology, whereas the $5^{\prime}$ halves of the genomes of each subgroup are more closely related to those of other virus groups than to each other (28). The target of this study, BYDV strain PAV, is a member of subgroup I and the most widespread BYDV in the United States. The $5^{\prime}$ half of the genome encodes open reading frames (ORFs) 1 and 2 , which code for 39- and 60-kDa proteins, respectively (Fig. 1). ORF 2 is expressed only by ribosomal frame-shifting as a $99-\mathrm{kDa}$ fusion with the ORF 1 product (7). It contains the consensus catalytic domain of RNA-dependent RNA polymerase (RdRp). Thus, we consider the 99-kDa product of ORFs $1+2$ to be the viralencoded core of the BYDV-PAV replicase. Except for the few amino acids conserved among all RdRps, it has no homology to the RdRps of subgroup II BYDVs (25).

Diseases caused by luteoviruses are controlled by the use of resistant and tolerant varieties or by insecticides to prevent virus spread by the aphid vector. The latter approach is not usually economical

Corresponding author: W. A. Miller; E-mail: wamiller@iastate.edu

Publication no. P-1998-0806-02R

(C) 1998 The American Phytopathological Society for BYDV hosts, nor is it environmentally desirable. The genes $Y d 2$ and $B d v l$ confer resistance to some BYDVs in certain lines of barley and wheat, respectively (5). Oat is usually the most severely affected by BYDV infection. No single gene for resistance to the virus has been identified in oats. Tolerance in widely used cultivars is attributed to two to four genes $(20,27)$. Breeders are limited to those lines that have natural levels of tolerance to BYDV, or they must introduce tolerance by classical breeding methods that
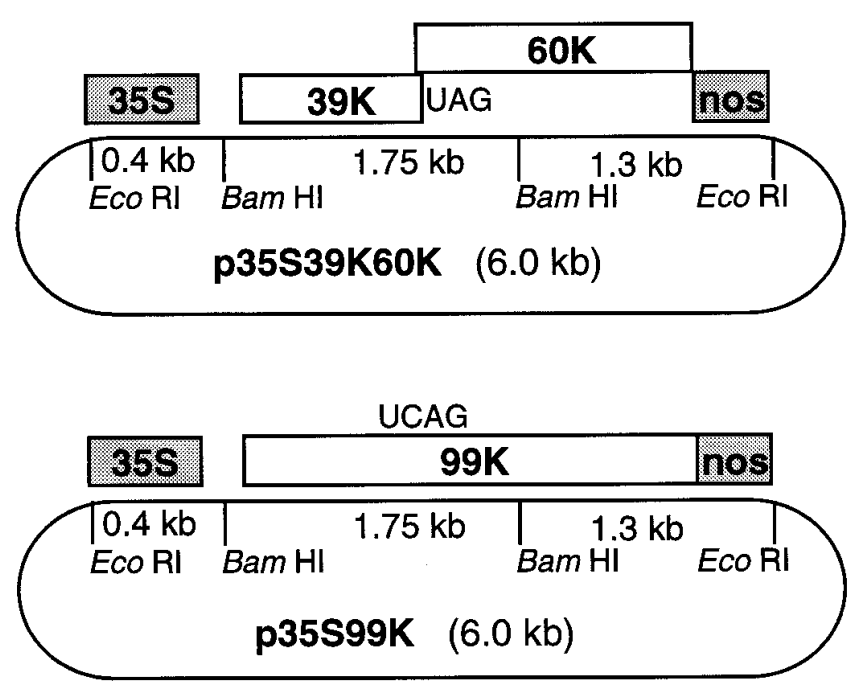

Fig. 1. Gene constructs used for oat transformation. The plasmid p35S39K60K contained the wild-type viral $5^{\prime}$ untranslated region followed by open reading frames (ORFs) 1 and 2 (39 and $60 \mathrm{kDa}$, respectively) under the control of the $35 \mathrm{~S}$ cauliflower mosaic virus promoter (35S) and nopaline synthase (nos) terminator (nos; shaded boxes). The plasmid p35S99K differs from p35S39K60K only by the insertion of a cytosine residue in the ORF 1 stop codon (UAG $\rightarrow$ UCAG). This mutation eliminates the stop codon and brings both genes into the same ORF. 
typically require many years. Many otherwise useful lines would not be practical, owing to their susceptibility to BYDV. Thus, the transgenic approach is an attractive means to rapidly introduce resistance to BYDVs in oats and other cereals in a single generation, providing freedom of more genotypes to be used in cereal breeding.

Numerous examples of virus-derived transgenes have been shown to provide resistance to viruses in a wide variety of hosts. Virusderived transgenes can affect resistance via their protein products $(10,31)$, via a sequence-specific suppression mechanism mediated by the transgenic transcript $(3,9,23)$, or by both mechanisms (32). Until recently, cereal crops have been difficult to transform. As a result, there are fewer examples of pathogen-derived resistance in cereals than in other plants $(13,15)$.

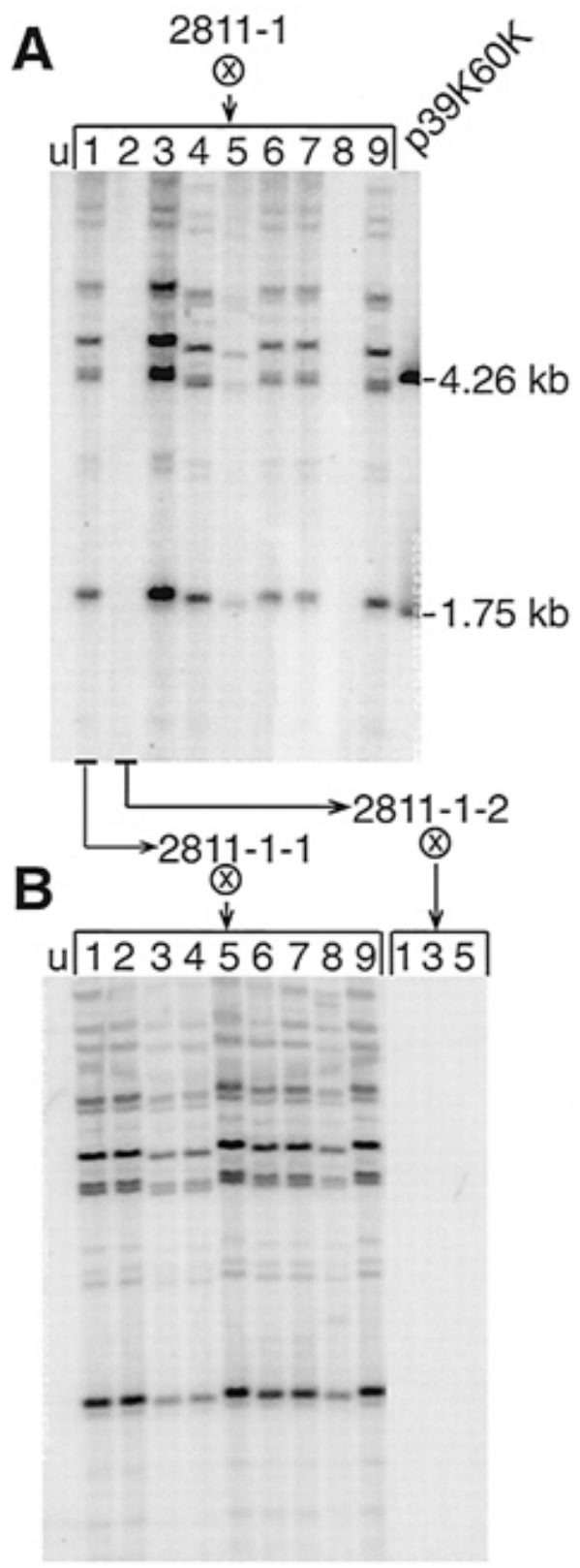

Fig. 2. Southern blot analysis of BamHI-digested DNA from line 2811. Blot was hybridized with a ${ }^{32} \mathrm{P}$-labeled EcoRI fragment of p35S39K60K spanning the entire viral sequence (Fig. 1). A, Nine individual plants (lanes 1 to 9) of the $\mathrm{T} 1$ generation. $\mathrm{u}=\mathrm{DNA}$ from an untransformed GAF/Park plant. p35S39K60K BamHI-digested plasmid DNA gave fragments of indicated size. Progeny of selfed $(\otimes)$ plants 2811-1-1 (lane 1, transgenic) and 2811-1-2 (lane 2, nontransgenic sibling) were used in further experiments. B, All nine progeny of the plant 2811-1-1 used in the test for resistance contained the transgene. All three tested progeny of plant 2811-1-2 were nontransgenic.
Virus-derived transgenes can confer resistance to luteoviruses. Coat protein genes gave moderate resistance to potato leafroll subgroup II luteovirus (PLRV) in potatoes $(1,2,16,17,44)$, but insignificant resistance to BYDV in oats and barley (26). Low to moderate resistance can be conferred by somaclonal variation during tissue culture $(26,34)$. In contrast, for many viruses $(11,23)$ including possibly PLRV (45), plants transformed with the viral RdRp gene can be extremely resistant to infection. Here, we describe oat plants (Avena sativa L.) transformed with a construct containing the $5^{\prime}$ half of the BYDV-PAV genome, which includes the RdRp gene. These plants ultimately show few symptoms and produce seed, while their nontransgenic segregants die from disease caused by virus infection. The reduction in symptoms may be by a novel mechanism that allows substantial virus accumulation.

\section{MATERIALS AND METHODS}

Gene constructs. Two constructs were used for oat transformation (Fig. 1). The construct p35S39K60K contained the 5' untranslated region (UTR) of BYDV-PAV and wild-type ORFs 1 and 2 preceded by the cauliflower mosaic virus double $35 \mathrm{~S}$ promoter and followed by the nopaline synthase (nos) transcription termination signal. The plasmid p35S39K60K was created in two steps. First, the p35SPAV5' (bases 1 to 1,596) construct was generated by polymerase chain reaction (PCR) using pPAV6 (7) full-length BYDV-PAV plasmid as a template. The upstream primer (5'-ACGGGATCCGAGTGAAGATTGACCATCTTCACA-3') contained a BamHI site and the first 23 nucleotides of the $5^{\prime}$ end of the BYDVPAV genomic RNA, and the downstream primer (5'-ATGAAGCTTGCACATTGGCATCCTTCTGATG-3') was complementary to viral bases 1,596 to 1,569 including a HindIII site. The BamHIHindIII-cut PCR fragment was gel-purified and cloned into pAGUS1 (40), which had been cut with the same enzymes, resulting in plasmid p35SPAV5'. Then the HindIII-Bst1107I (bases 1,591 to 2,787 ) fragment from pPAV6 was cloned into HindIIIEcoICRI-cut p35SPAV5', resulting in p35S39K60K. In the second construct, p35S99K, a stop codon of ORF 1 UAG, was mutated to UCAG, which brought ORFs 1 and 2 into the same ORF. If translated, this construct would produce only the $99-\mathrm{kDa}$ protein and not the $39-\mathrm{kDa}$ protein. This construct was generated by cloning the $B g l I I-S a c I$ (bases 856 to 2,453) fragment from pFLFSM4 (7) into p35S39K60K, which had been cut with the same enzymes. All the cloning junctions and the PCR-amplified regions were confirmed by double-stranded DNA sequencing (ABI 377 automated DNA sequencing system; Iowa State University Nucleic Acids Facility, Ames).

Transgenic plants. Oat transformation and selection was conducted according to Torbert et al. (46). The GAF/Park oat lines used for transformation were derived from single plant selections of the F7 generation of GAF/Park (4). Tissue cultures established from immature embryos of the F7 plant were transformed by microprojectile bombardment (41). Plasmids containing virus-derived transgenes were cobombarded with plasmid $\mathrm{pH} 24$, which encodes the nptII gene that served as a selectable marker (46). The plasmids were mixed at a 1:1 ratio, precipitated onto gold particles, and bombarded with the Biolistic PDS1000/He gun according to manufacturer's instructions (BioRad Laboratories, Hercules, CA). Selection of transgenic tissue cultures on medium containing $50 \mathrm{mg}$ of paramomycin per liter, plant regeneration, and subsequent growth in chambers were performed as described by Torbert et al. (46). T0 plants were allowed to self-pollinate for two generations to produce T2 progeny.

DNA extraction and Southern blot analysis. Plant genomic DNA was extracted using a hexadecyl trimethylammonium bromide method $(37,49)$. For Southern blot analysis, $20 \mu \mathrm{g}$ of genomic DNA was digested overnight with the BamHI (2.5 U/Mg of DNA) at $37^{\circ} \mathrm{C}$. DNA fragments were separated in a $0.9 \%$ agarose gel, blotted to a Hybond N+ nylon membrane (Amersham, Arlington 
Heights, IL), and hybridized as described by Wise et al. (49). ${ }^{32} \mathrm{P}-$ labeled probes were made by oligonucleotide random priming method using a Prime-a-Gene kit (Promega Corp., Madison, WI). A gel-purified EcoRI fragment of p35S39K60K (Fig. 1) was used as a template. Phosphorimager screens (Molecular Dynamics, Sunnyvale, CA) were exposed to radioactive membranes for 7 days.

RNA isolation and northern blot analysis. Total plant RNA was isolated from $100 \mathrm{mg}$ of fresh leaf tissue using the RNeasy plant total RNA kit (Qiagen, Inc., Los Angeles). RNA samples (2 to $3 \mu \mathrm{g}$ ) were subjected to electrophoresis in a $1 \%$ agarose formaldehyde denaturing gel, transferred to a Nylon GeneScreen (DuPont/ NEN, Boston) membrane, and hybridized with a complementary ${ }^{32} \mathrm{P}$-labeled RNA probe made as described by Seeley et al. (38). For transgenic mRNA detection, we used a probe complementary to the 5 -terminal $0.7 \mathrm{~kb}$ of the viral genomic RNA, which contains part of ORF 1. A probe complementary to the 3 '-terminal $1.5 \mathrm{~kb}$ of the PAV genome was used to detect viral genomic and subgenomic RNA accumulation. Radioactive blots were exposed to Phosphorimager screens for 2 to 5 days.

Growth and inoculation of plants. Oat plants were grown in chambers with a daytime temperature of $20^{\circ} \mathrm{C}$ and a nighttime temperature of $16^{\circ} \mathrm{C}$ with 12-h days for the first 5 weeks, followed by 16-h days in subsequent weeks. Plants were inoculated with an Illinois isolate of BYDV-PAV using viruliferous aphids (Rhopalosiphum padi). Aphids were allowed to feed on the plants for 2 days and then killed by spraying with pyrethrin insecticide (Ortho Tomato and Vegetable Insect Killer; Monsanto, St. Louis).

Enzyme-linked immunosorbent assay (ELISA). The procedure used for double-antibody sandwich (DAS)-ELISA was a modification of the method described by Diaco et al. (8). ELISA plates were coated with BYDV-PAV-specific polyclonal antibodies for $3 \mathrm{~h}$ at $37^{\circ} \mathrm{C}$, and then blocked with $1 \%$ fat-free Carnation dry milk solution (Nestlé, Glendale, CA). Plates were incubated overnight at $4^{\circ} \mathrm{C}$ with leaf sap extracted from at least four leaves per plant. The plates were then washed three times for 4 min each with phosphate-buffered saline containing $0.1 \%$ Tween. Alkaline phosphatase-BYDV-PAV polyclonal antibody conjugate prepared previously was added to the microtiter plates and incubated for $3 \mathrm{~h}$ at $37^{\circ} \mathrm{C}$. Plates were washed as above, and the disodium $p$-nitrophenyl phosphate $(5 \mathrm{mg}$ per tablet) substrate was added to the plates. ELISA readings $\left(A_{405}\right)$ were obtained from two replicate wells for each sample $1 \mathrm{~h}$ after addition of the substrate using a BioRad microplate reader and analyzed with Microplate manager software (BioRad Laboratories).

\section{RESULTS}

Transgenic plants. Oat (GAF/Park) tissue cultures were cobombarded with $\mathrm{pH} 24$ containing the selectable marker (nptII) and either p35S39K60K or p35S99K (Fig. 1). The construct p35S39K60K contained the $5^{\prime}$ half of the BYDV-PAV genome, which encodes ORFs 1 and 2, including the RdRp gene. p35S99K contained the same sequence as p35S39K60K, but with an insertion in the ORF 1 stop codon (UAG to UCAG), which brought both genes into the same ORF (99-kDa protein). Both constructs contained the $35 \mathrm{~S}$ promoter and the nos polyadenylation signal. Out of 42 bombarded callus lines capable of growing on the selective media, fertile plants were regenerated from 19 lines. The progeny (T1) of seven of these lines exhibited abnormal phenotypes: poor growth, stunting, or yellow leaves. The remaining 12 lines appeared normal and were characterized further.

Preliminary screening for resistance. T2 plants of four lines transformed with p35S39K60K, eight lines transformed with p35S99K, and untransformed controls were screened for resistance to BYDV-PAV. Ten 2-week-old plants of each line were inoculated with 25 to 30 viruliferous aphids per plant. Initially, symptoms of virus infection developed 7 days after inoculation on all plants: leaves became stiff with subsequent yellowing and necro- sis. About 2 weeks later, 8 out of 10 plants of line 2811, which carried the $\mathrm{p} 35 \mathrm{~S} 39 \mathrm{~K} 60 \mathrm{~K}$ construct, started to recover; they produced new, healthy-looking tillers and leaves and eventually flowered and produced seed. Of the 131 plants in all other transgenic and nontransgenic lines, $70 \%$ died by 40 days after inoculation. The remaining $30 \%$ were extremely stunted and necrotic.

Transgene segregation. The transformation process itself including passage through tissue culture can improve resistance to luteoviruses in the absence of the transgene $(19,26,34)$. To rule out
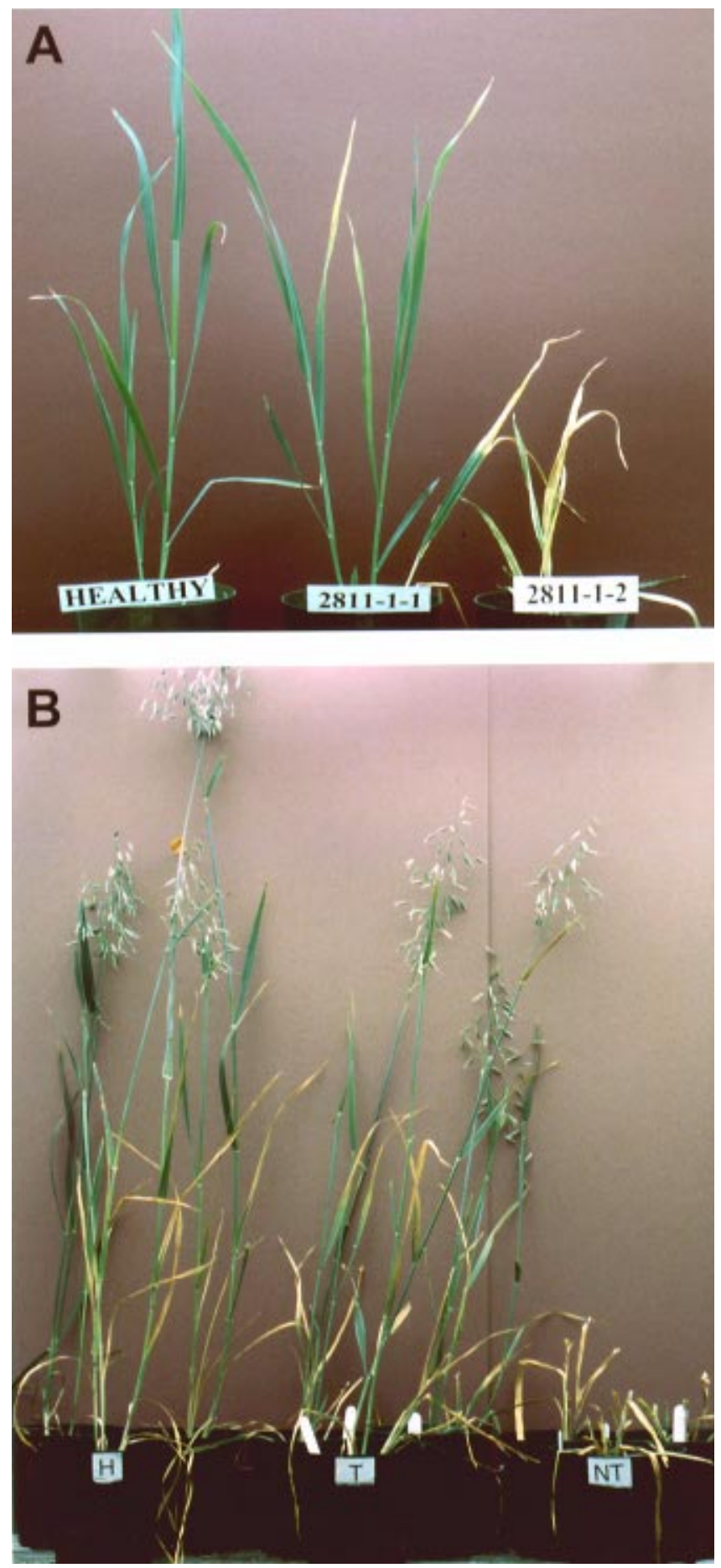

Fig. 3. Oats inoculated with barley yellow dwarf virus strain PAV and uninfected controls. Typical plants are shown. A, T2 plants, 7.5 weeks old, 4 weeks postinoculation (wpi). Healthy, plants not inoculated with the virus; 2811-11 , progeny of the selfed transgenic plant 2811-1-1; and 2811-1-2, progeny of the selfed nontransgenic plant 2811-1-2. B, Three pots each of T3 plants 11.5 weeks old, 7 wpi. $\mathrm{H}$, plants not inoculated with the virus; $\mathrm{T}$, transgenic plants, progeny of 2811-1-1-2 (Fig. 2B); and NT, nontransgenic plants, progeny of 2811-1-2-5 (Fig. 2B). 
this possibility, all plants used for comparison must be descended from the same tissue culture and transformation event. This was done by using nontransgenic segregants of line 2811 as a negative control to further characterize line 2811 for transgenic resistance to BYDV-PAV. To identify transgene-negative plants, Southern blot hybridizations were performed on genomic DNA of nine T1 individuals using the entire viral insert in $\mathrm{p} 35 \mathrm{~S} 39 \mathrm{~K} 60 \mathrm{~K}$ as a probe (Fig. 1). All of the transgenic plants in line 2811 (Fig. 2A) and all other transgenic lines (data not shown) showed complex sets of hybridizing bands. In line 2811, these resulted most likely from multiple insertions of rearranged, concatemerized plasmid DNA at a single locus, because T2 plants either had all or none of the bands. Such irregular patterns segregating as a single locus are common in biolistic transformation $(18,33,41)$. Strong signals in bands of the expected sizes (1.75 and $4.26 \mathrm{~kb}$ ) (Fig. 2A) indicate that several of the copies were not likely to be rearranged. Descendants of these initial line 2811 transformants were named by the number arbitrarily assigned to the parental plant of each generation separated by hyphens from the number of the plant of the next generation. T1 progeny from T0 plant number 2811-1, named 2811-1-1 and 2811-1-2, were found to contain and lack, respectively, transgenic DNA (Fig. 2A). The descendants of these two plants were chosen for further study.

Nontransgenic T2 segregants of line 2811 were susceptible to virus infection. Progeny of the selfed plants 2811-1-1 (transgenic) and 2811-1-2 (nontransgenic segregants) were tested for BYDVPAV resistance. First, the presence or absence of transgenes in the inoculated T2 plants was verified by Southern analysis. All nine tested progeny of 2811-1-1 contained the transgene (Fig. 2B), whereas all three tested progeny of plant 2811-1-2 lacked the transgene, as expected. Three-week-old plants were inoculated with five viruliferous aphids per plant. In this experiment, we used lower initial inoculum (number of aphids) and older plants than in the preliminary screening in an unsuccessful attempt to decrease the severity of disease that was observed in the first screen. As in the first screen, from 10 to 17 days after inoculation, there was little difference in symptoms between transgenic and nontransgenic plants: all plants exhibited stiffness and yellowing of the leaves. Subsequently, all eight inoculated progeny of plant 2811-1-1 began to recover, whereas all eight inoculated progeny of the plant 2811-1-2 showed more severe symptoms and eventually died without heading (Fig. 3A). Infected transgenic plants, although exhibiting a tolerant phenotype, were slightly shorter than the uninfected plants (Fig. 3A). No difference was observed between uninfected transgenic and nontransgenic plants (data not shown).

Northern blots probed with RNA complementary to the $3^{\prime}$ end of the BYDV-PAV genomic RNA revealed the presence of viral

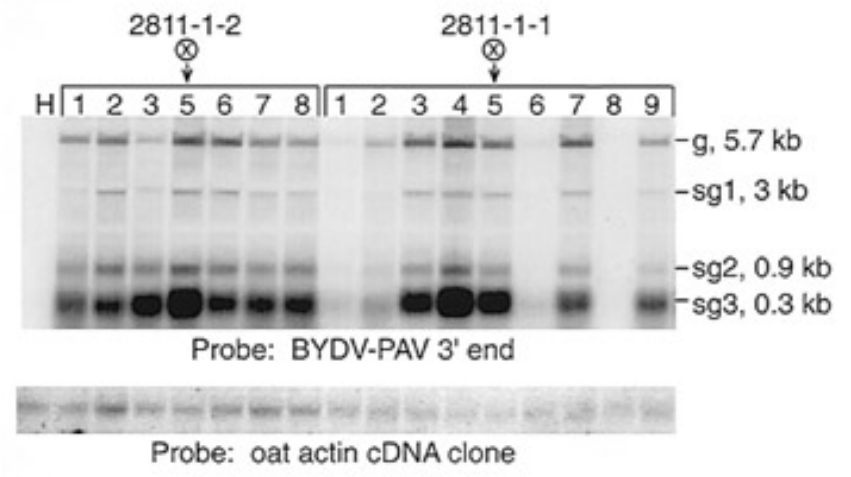

Fig. 4. Viral RNA accumulation in infected plants. Following electrophoresis and transfer to a nylon membrane, total plant RNA was hybridized with ${ }^{32} \mathrm{P}$ labeled RNA complementary to the 3'-terminal 1,450 bases of the barley yellow dwarf virus (BYDV) strain PAV genome (upper panel). Sizes of BYDV-PAV genomic (g) and subgenomic (sg) RNAs are indicated at right. Lane $\mathrm{H}$ contains RNA from a healthy plant; lane numbers designate individual progeny of plants 2811-1-2 and 2811-1-1. The same membrane was stripped and reprobed for the oat actin mRNA as reference for quantification purposes (lower panel). genomic RNA and the 3 '-coterminal subgenomic RNAs in all inoculated plants (Fig. 4). The level of viral RNA varied twofold in the nontransgenic line 2811-1-2 as measured by Phosphorimagery, whereas the amount in infected transgenic line 2811-1-1 varied by over 20-fold, with extremely low levels in three of the plants (Fig. 4, line 2811-1-1, plants 1, 6, and 8). No viral RNA was detected in plant number 8 (Fig. 4).

Transgenic mRNA in plants. To test for stability of inheritance of the tolerant phenotype, progeny seed of the transgenic plant 2811-1-1-2 and the nontransgenic plant 2811-1-2-5 (T3 generation) were planted for subsequent inoculation. Before infecting the plants, transgenic mRNA accumulation was monitored by northern blot analysis of total plant RNA. Transgenic mRNA was detected in all seven of the progeny of 2811-1-1-2 and absent in the two tested progeny of 2811-1-2-5 (Fig. 5). In addition to the mRNA of expected size $(2.8 \mathrm{~kb})$, a smear of lower-molecular-mass RNA was present. The apparent bands in this smear were due to "shadowing" caused by the highly abundant ribosomal RNAs. To test for nonspecific degradation, the membrane was stripped and rehybridized with a probe specific for the oat actin gene. Hybridization bands appeared sharp, with no noticeable degradation (Fig. 5), suggesting that the low-molecular-mass transgenic mRNA was not entirely due to nonspecific ribonuclease contamination during sample preparation.

All T3-generation transgenic plants are resistant. At the age of 4 weeks, the above plants were inoculated as in the previous experiment. Disease development and recovery by the transgenic plants were the same as in the previous experiments. All seven transgenic plants tested showed the tolerant phenotype (Fig. 3B). They headed and produced seed. At maturity, inoculated transgenic plants averaged $80 \pm 6 \mathrm{~cm}$ tall and yielded $1.5 \pm 0.5 \mathrm{~g}$ of seed per plant, compared with $94 \pm 6 \mathrm{~cm}$ height and $2.6 \pm 0.4 \mathrm{~g}$ of seed per plant yielded by uninoculated plants. (Growth conditions were not optimized for seed production.) Unlike the previous experiments, one of the seven nontransgenic plants tested exhibited some tolerance: it reached $89 \mathrm{~cm}$ in height and flowered, but produced only $0.1 \mathrm{~g}$ of seed. The other six inoculated nontransgenic plants died before reaching $25 \mathrm{~cm}$ (Fig. 3B).

Virion accumulation in inoculated plants was determined before ( 3 weeks postinoculation, wpi) and after ( 6 wpi) the transgenic plants recovered from disease symptoms. ELISA readings varied widely between plants (Fig. 6). The average ELISA reading in the seven transgenic plants at 3 wpi $\left(A_{405}=0.51\right.$, range $=0.06$ to

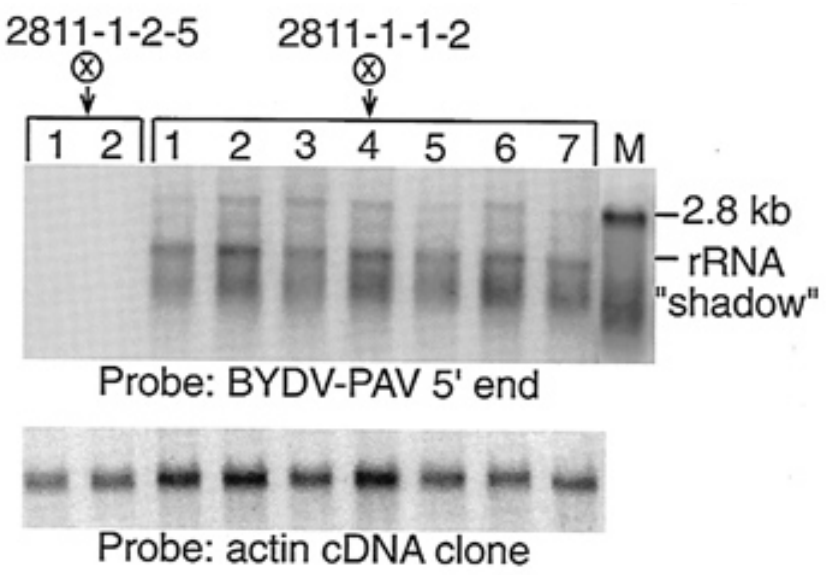

Fig. 5. Transgenic mRNA detected in plants by northern blot hybridization. After denaturing agarose gel electrophoresis and transfer to a membrane, total plant RNA was hybridized with the ${ }^{32} \mathrm{P}$-labeled probe complementary to the $5^{\prime}$ $0.7 \mathrm{~kb}$ of the viral genome (upper panel). Numbers above the lanes designate individual progeny of plants 2811-1-2-5 and 2811-1-1-2. In vitro transcript from EcoRI-digested pPAV6 corresponding to the transgenic mRNA was used as a size marker (M, $2.8 \mathrm{~kb})$. The same membrane was stripped and rehybridized with the ${ }^{32} \mathrm{P}$-labeled RNA probe derived from the cDNA clone of the oat actin gene (lower panel). 
1.08) did not differ substantially from that of the nontransgenic plants $\left(A_{405}=0.56\right.$, range $=0.29$ to 0.91$)$. At 6 wpi, the new green tissue was sampled from the transgenic plants, whereas the remaining necrotic tissue was sampled from the nontransgenic plants. The average ELISA value from the transgenic plants $\left(A_{405}=0.54\right.$, standard deviation $[\mathrm{SD}]=0.28$ ) was less than half that of the nontransgenic plants $\left(A_{405}=1.22, \mathrm{SD}=0.52\right)$. However the standard deviations were large. Given the necrotic nature of the nontransgenic material, it is likely that virus titer was reduced, because the plants were nearly dead. Moreover, the dried nature of this tissue reduced efficiency of virus extraction for ELISA. Thus, on average, the healthy recovered tillers of the transgenic plants harbored less virus than the nontransgenic plants. It is noteworthy that one transgenic plant (Fig. 6A, plant 3) gave ELISA readings not significantly above background at both sampling dates. However, it did not appear any healthier than the other recovered plants with higher ELISA readings. Thus, there was not an obvious correlation between ELISA readings and symptom phenotype.

\section{DISCUSSION}

We constructed a line of transgenic oats that shows dramatically reduced disease symptoms when inoculated with BYDV-PAV. Transgenic plants recovered and produced seed, while the nontransgenic siblings died from disease. While the transgenic plants had lower average virus titer, some of the recovered plants still contained significant virus levels. Thus, it is not certain whether transgenic plants of line 2811 exhibited true resistance (restriction of virus accumulation) or tolerance (virus accumulation, but little or no symptoms) as defined by Cooper and Jones (6), or both. However, some transgenic individuals had low RNA (Fig. 4) or virion (Fig. 6) accumulation, while all nontransgenic plants had high levels of both. The large variation in ELISA readings and virus RNA levels may have resulted from uneven distribution of the virus within plants, although four to five leaves were sampled from each plant tested for both northern and ELISA analyses. Furthermore, by the time virus and RNA were sampled from recovered plants, the level of virus and RNA used for comparison in susceptible plants may have been reduced because of the severe tissue necrosis. Therefore, the difference in virus and viral RNA levels in recovered versus susceptible plants at $6 \mathrm{wpi}$ (Figs. 4 and 6) may be much greater than it appears to be.

The mechanism of action of the transgene is unknown. Resistance may be mediated by the RNA or by the encoded protein. RNA-mediated resistance may be trans-dominant inhibition conferred by the viral $5^{\prime}$ UTR in the transgene. The $5^{\prime}$ UTR plays a role in cap-independent translation of the viral genome (48) that may be disrupted in trans by the copy of the 5' UTR on the transgenic mRNA. Alternatively, because the $5^{\prime}$ UTR is complementary to the presumed replication origin at the $3^{\prime}$ end of the (-) strand, it could disrupt replication of invading viral RNA.

Another possibility is that the transgenic RNA facilitates degradation of invading viral RNA by RNA-mediated gene silencing, as has been observed in transgenic resistance to other RNA viruses $(3,9)$. It has been proposed that aberrant transgenic mRNA is specifically degraded in plant cells, causing the homologous invading virus RNA to be recognized and degraded by the same cellular machinery $(3,9)$. Some of the transgenic RNA in line 2811-1-1 appears degraded (Fig. 5), consistent with the model, but intact transgenic mRNA is also present. Rather than a specific degradation mechanism, the shorter transgenic RNAs could be explained by transcription of truncated forms of the transgene that arise in the rearrangements revealed in Southern blots.

Resistance in line 2811 is very unlikely to be "replicase-mediated," because the ribosomal frame-shifting needed for translation of the RdRp is dependent on a sequence in the $3^{\prime}$ end of the BYDV-PAV genome (47) that is absent from the transgene. Not enough transgenic plants were tested to determine whether the inframe mutant (p35S99K) is capable of conferring resistance.
A recovery phenomenon, similar to that which we observed, has been reported in RNA-mediated resistance (21), replicase-mediated resistance $(31,42,43)$, and natural resistance (35). In those cases, recovery coincided with substantial reduction in virus and viral RNA levels. In contrast, some of the healthy recovered transgenic plants of line 2811 had high virion and RNA levels and were indistinguishable from those with reduced virus titer. This may resemble a mechanism of transgenic resistance to pepper mild mottle tobamovirus in which some plants of a resistant line transformed with a truncated $54-\mathrm{kDa}$ gene (RdRp catalytic domain) showed delayed and reduced symptoms, while still supporting high levels of virus accumulation (43). An example also exists in nontransgenic tobacco plants infected with tobacco ring spot virus. They show severe symptoms until virus enters the meristematic tissue, after which the plants can recover with few symptoms, despite the presence of substantial levels of virus (36). New models must be considered to explain this recovery despite substantial virus titer. If disease results from an active host response, the transgene may somehow induce the host to not recognize and respond negatively to the virus. On the other hand, the transgene may induce a positive host response that prevents symptom-induction by the virus.

Although the inoculated transgenic line 2811 plants show reduced yield and significant virus titer, this transgene strategy may ultimately be useful agronomically for three reasons. First, most oat cultivars are much less susceptible to BYDV infection. In fact, the GAF/Park line (4) is the most highly susceptible oat line we have seen. The huge difference in symptom severity between the nontransgenic GAF/Park plants and transgenic plants (Fig. 3) demonstrates the dramatic ability of the transgene construct to improve resistance. Thus, if a similar construct were engineered or crossed into elite varieties that already show some tolerance to BYDV-PAV, the combined natural and transgenic tolerance might provide an even higher level of resistance than exists in any cultivar available (2). Second, the growth chamber and inoculation conditions used here greatly favor virus replication and disease development. In a field situation with less inoculum pressure and less optimal con-
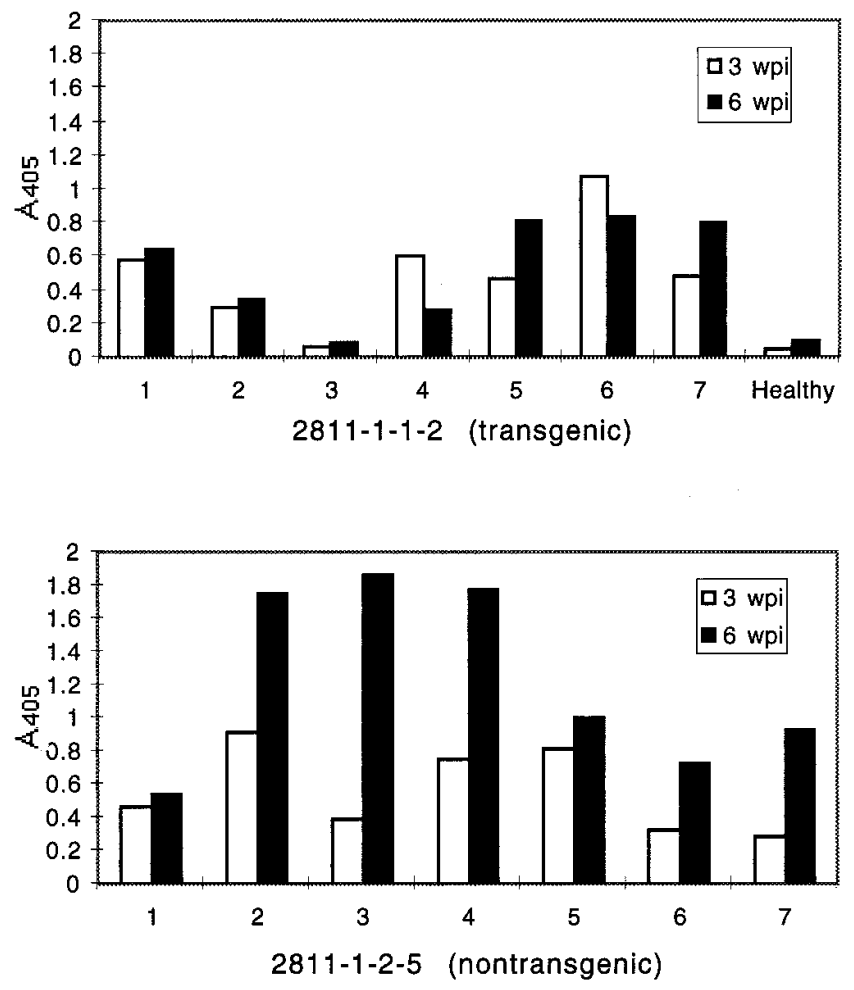

Fig. 6. Barley yellow dwarf virus strain PAV virion accumulation in inoculated individual progeny of transgenic and nontransgenic segregants, measured by double-antibody sandwich enzyme-linked immunosorbent assay (described in Materials and Methods). 
ditions for virus replication, the symptoms may be milder and the transgenic lines may more closely approach the yield of uninfected plants. Third, tolerance may be more durable than resistance. There would be much weaker (if any) selection for a resistance-breaking virus strain in contrast to the use of highly resistant plants. Conventional oat breeding has led to tolerant rather than resistant lines, based on the lack of strong correlation between virus titer and symptoms including yield reduction $(5,39)$. Many wild grasses also have evolved tolerance rather than resistance (12). Thus, tolerance rather than resistance seems to have evolved as an effective way by which wild and domesticated plants cope with BYDV.

In summary, the transgenic strategy shown here is a promising first step for transgenic resistance to BYDVs in oats, and no doubt barley and wheat as well. However, it is clear that more work is necessary to investigate the mechanism of resistance or tolerance and to determine how it will behave in field trials.

\section{ACKNOWLEDGMENTS}

This research was funded by the North Central Biotechnical Program (grant 593-0213-20), the Quaker Oats Company, and the USDA Biotechnology Risk Assessment Research Grant Program (grant 94-39210-0531). This is paper no. J-17787 of the Iowa State University Agricultural and Home Economics Experiment Station Project 3324, and is supported by Hatch Act and State of Iowa funds. We thank H. Rines, R. Beckett, G. Patrick, M. Walter, J. Rohozinski, K. Gobelman-Werner, A. Bush, and R. Wise for technical assistance and advice; and J. Colbert for providing the oat actin cDNA clone.

\section{LITERATURE CITED}

1. Barker, H., Reavy, B., Kumar, A., Webster, K. D., and Mayo, M. A. 1992. Restricted virus multiplication in potatoes transformed with the coat protein gene of potato leafroll luteovirus: Similarities with a type of host gene-mediated resistance. Ann. Appl. Ecol. 120:55-64.

2. Barker, H., Webster, K. D., Jolly, C. A., Reavy, B., Kumar, A., and Mayo, M. A. 1994. Enhancement of resistance to potato leafroll virus multiplication in potato by combining the effects of host genes and transgenes. Mol. Plant-Microbe Interact. 7:528-530.

3. Baulcombe, D. C. 1996. RNA as a target and an initiator of post-transcriptional gene silencing in transgenic plants. Plant Mol. Biol. 32:79-88.

4. Bregitzer, P., Somers, D. A., and Rines, H. W. 1989. Development and characterization of friable, embryogenic oat callus. Crop Sci. 29:798-803.

5. Burnett, P. A., Comeau, A., and Qualset, C. O. 1995. Host plant tolerance or resistance for control of barley yellow dwarf. Pages 321-343 in: Barley Yellow Dwarf: 40 Years of Progress. C. J. D’Arcy and P. A. Burnett, eds. The American Phytopathological Society, St. Paul, MN.

6. Cooper, J. I., and Jones, A. T. 1983. Responses of plants to viruses: Proposals for the use of terms. Phytopathology 73:127-128.

7. Di, R., Dinesh-Kumar, S. P., and Miller, W. A. 1993. Translational frameshifting by barley yellow dwarf virus RNA (PAV serotype) in Escherichia coli and in eukaryotic cell-free extracts. Mol. Plant-Microbe Interact. 6:444-452.

8. Diaco, R., Lister, R. M., Hill, J. H., and Durand, D. P. 1986. Demonstration of serological relationships among isolates of barley yellow dwarf virus by using polyclonal and monoclonal antibodies. J. Gen. Virol. 67:353-362.

9. Dougherty, W. G., Lindbo, J. A., Smith, H. A., Parks, T. D., Swaney, S., and Proebsting, W. M. 1994. RNA-mediated virus resistance in transgenic plants: Exploitation of a cellular pathway possibly involved in RNA degradation. Mol. Plant-Microbe Interact. 7:544-552.

10. Fitchen, J. H., and Beachy, R. N. 1993. Genetically engineered protection against viruses in transgenic plants. Annu. Rev. Microbiol. 47:739-763.

11. Golemboski, D. B., Lomonossoff, G. P., and Zaitlin, M. 1990. Plants transformed with a tobacco mosaic virus nonstructural gene sequence are resistant to the virus. Proc. Natl. Acad. Sci. U.S.A. 87:6311-6315.

12. Grafton, K. F., Poehlman, J. M., Sehgal, O. P., and Sechler, D. T. 1982. Tall fescue as a natural host and aphid vectors of barley yellow dwarf virus in Missouri (Rhopalosiphum padi). Plant Dis. 66:318-320.

13. Hayakawa, T., Zhu, Y., Itoh, K., Kimura, Y., Izawa, T., Shimamoto, K., and Totiyama, S. 1992. Genetically engineered rice resistant to rice stripe virus, an insect-transmitted virus. Proc. Natl. Acad. Sci. U.S.A. 89:9865-9869.

14. Hewings, A. D., and Eastman, C. E. 1995. Epidemiology of barley yellow dwarf in North America. Pages 75-106 in: Barley Yellow Dwarf: 40 Years of Progress. C. J. D'Arcy and P. A. Burnett, eds. The American Phytopathological Society, St. Paul, MN.
15. Huntley, C. C., and Hall, T. C. 1996. Interference with brome mosaic virus replication in transgenic rice. Mol. Plant-Microbe Interact. 9:164-170.

16. Kawchuk, L. M., Martin, R. R., and McPherson, J. 1990. Resistance in transgenic potato expressing the potato leafroll virus coat protein gene. Mol. Plant-Microbe Interact. 3:301-307.

17. Kawchuk, L. M., Martin, R. R., and McPherson, J. 1991. Sense and antisense RNA-mediated resistance to potato leafroll virus in Russet Burbank potato plants. Mol. Plant-Microbe Interact. 4:247-253.

18. Klein, T. M., Kornstein, L., Sanford, J. C., and Fromm, M. E. 1989. Genetic transformation of maize cells by particle bombardment. Plant Physiol. 91:440-444.

19. Koev, G. 1996. Characterization of transgenic oats for resistance to BYDV and assessment of possible risks. M.S. thesis. Iowa State University, Ames.

20. Landry, B., Comeau, A., Minvielle, F., and St-Pierre, C. A. 1984. Genetic analysis of resistance to barley yellow dwarf virus in hybrids between Avena sativa cv. Lamar and virus resistant lines of Avena sterilis. Crop Sci. 24:337-340.

21. Lindbo, J. A., and Dougherty, W. G. 1992. Pathogen-derived resistance to a potyvirus: Immune and resistant phenotypes in transgenic tobacco expressing altered forms of a potyvirus coat protein nucleotide sequence. Mol. Plant-Microbe Interact. 5:144-153.

22. Lister, R. M., and Ranieri, R. 1995. Distribution and economic importance of barley yellow dwarf. Pages 29-53 in: Barley Yellow Dwarf: 40 Years of Progress. C. J. D'Arcy and P. Burnett, eds. The American Phytopathological Society, St. Paul, MN.

23. Longstaff, M., Brigneti, G., Boccard, F., Chapman, S., and Baulcombe, D. 1993. Extreme resistance to potato virus $\mathrm{X}$ infection in plants expressing a modified component of the putative viral replicase. EMBO (Eur. Mol. Biol. Organ.) J. 12:379-386.

24. Martin, R. R., and D'Arcy, C. J. 1995. Taxonomy of barley yellow dwarf viruses. Pages 203-214 in: Barley Yellow Dwarf: 40 Years of Progress. C. J. D'Arcy and P. A. Burnett, eds. The American Phytopathological Society, St. Paul, MN.

25. Mayo, M. A., and Ziegler-Graff, V. 1996. Molecular biology of luteoviruses. Adv. Virus Res. 46:413-460.

26. McGrath, P. F., Vincent, J. R., Lei, C.-H., Pawlowski, W. P., Torbert, K. A., Gu, W., Kaeppler, H. F., Wan, Y., Lemaux, P. G., Rines, H. R., Somers, D. A., Larkins, B. A., and Lister, R. M. 1997. Coat protein-mediated resistance to isolates of barley yellow dwarf in oats and barley. Eur. J. Plant Pathol. 103:695-710.

27. McKenzie, R. I. H., Burnett, P. A., Gill, C. C., Comeau, A., and Brown, P. D. 1985. Inheritance of tolerance to barley yellow dwarf virus in oats. Euphytica 34:681-687.

28. Miller, W. A., Dinesh-Kumar, S. P., and Paul, C. P. 1995. Luteovirus gene expression. Crit. Rev. Plant Sci. 14:179-211.

29. Miller, W. A., and Rasochova, L. 1997. Barley yellow dwarf viruses. Annu. Rev. Phytopathol. 35:167-190.

30. Oerke, E. C., Dehne, H. W., Schonbeck, F., and Weber, A. 1994. Crop Production and Crop Protection: Estimated Losses in Major Food and Cash Crops. Elsevier, New York.

31. Palukaitis, P., and Zaitlin, M. 1997. Replicase-mediated resistance to plant virus disease. Adv. Virus Res. 48:349-377.

32. Pang, S.-Z., Jan, F.-J., Carney, K., Stout, J., Tricoli, D. M., Quemada, H. D., and Gonsalves, D. 1996. Post-transcriptional transgene silencing and consequent tospovirus resistance in transgenic lettuce are affected by transgene dosage and plant development. Plant J. 9:899-909.

33. Pawlowski, W. P., and Somers, D. A. 1996. Transgene inheritance in plants genetically engineered by microprojectile bombardment. Mol. Biotechnol. 6:17-30.

34. Presting, G. G., Smith, O. P., and Brown, C. R. 1995. Resistance to potato leafroll virus in potato plants transformed with the coat protein gene or with vector control constructs. Phytopathology 85:436-442.

35. Ratcliff, F., Harrison, B. D., and Baulcombe, D. C. 1997. A similarity between viral defense and gene silencing in plants. Science 276:1558-1560.

36. Roberts, D. A., Christie, R. G., and Archer, M. C., Jr. 1970. Infection of apical initials in tobacco shoot meristems by tobacco ringspot virus. Virology 42:217-220.

37. Saghai-Maroof, M. A., Soliman, K. M., Jorgensen, R. A., and Allard, R. W. 1984. Ribosomal DNA spacer-length polymorphisms in barley: Mendelian inheritance, chromosomal location, and population dynamics. Proc. Natl. Acad. Sci. U.S.A. 81:8014-8018.

38. Seeley, K. A., Byrne, D. H., and Colbert, J. T. 1992. Red light-independent instability of oat phytochrome mRNA in vivo. Plant Cell 4:29-38.

39. Skaria, M., Lister, R. M., Foster, J. E., and Shaner, G. 1985. Virus content as an index of symptomatic resistance to barley yellow dwarf virus in cereals. Phytopathology 75:212-216.

40. Skuzeski, J. M., Nichols, L. M., and Gesteland, R. F. 1990. Analysis of leaky viral translation termination codons in vivo by transient expression of improved $\beta$-glucuronidase vectors. Plant Mol. Biol. 15:65-79. 
41. Somers, D. A., Rines, H. W., Gu, W., Kaeppler, H. F., and Bushnell, W. R. 1992. Fertile, transgenic oat plants. Bio/Technology 10:15891594.

42. Tenllado, F., Garcia-Luque, I., Serra, M. T., and Diaz-Ruiz, J. R. 1995. Nicotiana benthamiana plants transformed with the 54-kDa region of the pepper mild mottle tobamovirus replicase gene exhibit two types of resistance responses against viral infection. Virology 211:170-183.

43. Tenllado, F., Garcia-Luque, I., Serra, M. T., and Diaz-Ruiz, J. R. 1996. Resistance to pepper mild mottle tobamovirus conferred by the $54-\mathrm{kDa}$ gene sequence in transgenic plants does not require expression of the wild-type 54-kDa protein. Virology 219:330-335.

44. Thomas, P. E., Kaniewski, W. K., and Lawson, E. C. 1997. Reduced spread of potato leafroll virus in potatoes transformed with the potato leafroll virus coat protein gene. Plant Dis. 81:1447-1453.

45. Thomas, P. E., Kaniewski, W. K., Reed, G. L., and Lawson, E. C. 1995.
Transgenic resistance to potato leafroll virus in Russet Burbank potatoes. Pages 551-554 in: Environmental Biotic Factors in Integrated Plant Disease Control. M. Manka, ed. The Polish Phytopathological Society, Poznan.

46. Torbert, K. A., Rines, H. W., and Somers, D. A. 1995. Use of paramomycin as a selective agent for oat transformation. Plant Cell Rep. 14:635-640.

47. Wang, S., and Miller, W. A. 1995. A sequence located 4.5 to 5 kilobases from the $5^{\prime}$ end of the barley yellow dwarf virus (PAV) genome strongly stimulates translation of uncapped mRNA. J. Biol. Chem. 270:13446-13452.

48. Wang, S. P., Browning, K. S., and Miller, W. A. 1997. A viral sequence in the $3^{\prime}$ untranslated region mimics a $5^{\prime}$ cap in facilitating translation of uncapped mRNA. EMBO (Eur. Mol. Biol. Organ.) J. 16:4107-4116.

49. Wise, R. P., and Schnable, P. S. 1994. Mapping complementary genes in maize: Positioning the $r f 1$ and $r f 2$ nuclear-fertility restorer loci of Texas (T) cytoplasm relative to RFLP and visible markers. Theor. Appl. Genet. 88:785-795 